\title{
The Impact of COVID - 19 on Employee's Job Security and Job Satisfaction of Bangladesh
}

\author{
Monija Islam* \\ Tanveer Muhammad Al-Shams
}

*Lecturer, Department of Government and Politics, Asian University of Bangladesh, BANGLADESH Assistant Professor, Department of Business Administration, Asian University of Bangladesh, BANGLADESH

*(imonija7@gmail.com)

This journal is licensed under a Creative Commons Attribution-Noncommercial 4.0 International License (CC-BY-NC).

Articles can be read and shared for noncommercial purposes under the following conditions:

- BY: Attribution must be given to the original source (Attribution)

- NC: Works may not be used for commercial purposes (Noncommercial)

This license lets others remix, tweak, and build upon your work non-commercially, and although their new works must also acknowledge you and be non-commercial, they don't have to license their derivative works on the same terms.

License Deed Link: http://creativecommons.org/licenses/by-nc/4.0/

Legal Code Link: http://creativecommons.org/licenses/by-nc/4.0/legalcode

$A B C$ Research Alert uses the CC BY-NC to protect the author's work from misuse.

\begin{abstract}
This paper presents a comprehensive diagnosis of Job Security and Job Satisfaction of different service sector in Bangladesh. The different service sector job holders are in a precarious situation in terms of their job security. The survey questionnaire was modeled to measure the job security $\&$ job satisfaction of an employee in this Covid-19 pandemic. In this study, we investigate the vacillation of job security for different service sector employees. Job security and Job Satisfaction is one of the vexed questions here in the COVID-19 pandemic situation. It focuses on the relative importance of Job Security and job satisfaction factors and their impact on the employment. The result shows that working conditions, chance to try my own methods and coworkers harmony are the most important factors contributing to job satisfaction during COVID-19. For this purpose, we formed questionnaire of 300 service sector employees such as Teachers School, College and University; bankers, doctors, engineers etc. to find out the actual scenarios. It also investigates the influence of age, gender and managerial/non managerial differences on the attitude towards job satisfaction. The study also examines the differences between intrinsic and extrinsic job satisfaction factors. Based on the findings, the employees at different service sector they were slightly satisfied with their jobs. Service sector employees are agonizing mostly due to this problem.
\end{abstract}

Keywords

Job Insecurity, Job Satisfaction, Service Sector, COVID-19, Employment

\section{INTRODUCTION}

This Pandemic of Covid-19 is widely discussed in this world now. Because it has affected world economy heavily. This has heavily affected different industries of the world that also affected the employee's job. The research is carried out with an objective to find out how job security and job satisfaction of employees is affected by the Covid-19. This research wants to find out what is happening with the employees of different industries in this Covid-19 situation whether it is positive or it's negative. How they affect the economy of Bangladesh. 
The COVID-19 pandemic has had far-reaching consequences beyond the spread of the disease itself and efforts to quarantine it. As the SARS-CoV-2 virus has spread around the globe, concerns have shifted from supply-side manufacturing issues to decreased business in the services sector. The pandemic caused the largest global recession in history, with more than a third of the global population at the time being placed on lockdown.

Supply shortages are expected to affect a number of sectors due to panic buying, increased usage of goods to fight the pandemic, and disruption to factories and logistics in mainland China. There have been instances of price gouging. There have been widespread reports of shortages of pharmaceuticals, with many areas seeing panic buying and consequent shortages of food and other essential grocery items. The technology industry, in particular, has been warning about delays to shipments of electronic goods.

Global stock markets fell on 24 February 2020 due to a significant rise in the number of COVID-19 cases outside mainland China. By 28 February 2020, stock markets worldwide saw their largest single-week declines since the 2008 financial crisis. Global stock markets crashed in March 2020, with falls of several percent in the world's major indices.

Possible instability generated by an outbreak and associated behavioral changes could result in temporary food shortages, price spikes, and disruption to markets. Such price rises would be felt most by vulnerable populations who depend on markets for their food as well as those already depending on humanitarian assistance to maintain their livelihoods and food access. As observed in the 2007-2008 food prices crisis, the additional inflationary effect of protectionist policies through import tariffs and export bans could cause a significant increase in the number of people facing severe food insecurity worldwide (Manavalan \& Ganapathy, 2014).

As the pandemic spreads, global conferences and events across technology, fashion, and sports are being cancelled or postponed. While the monetary impact on the travel and trade industry is yet to be estimated, it is likely to be in the billions and increasing.

Job satisfaction, an unquantifiable metric, is defined as a positive emotional response you experience when doing your job or when you are present at work. Leading organizations are now trying to measure this feeling, with job satisfaction surveys becoming a staple at most workplaces. It's important to remember that job satisfaction varies from employee to employee. In the same workplace under the same conditions, the factors that help one employee feel good about their job may not apply to another employee. For this reason, it is essential to have a multidimensional approach to employee satisfaction, covering the following areas:

- The challenging nature of work, pushing employees to new heights

- A level of convenience (short commutes, access to the right digital tools, and flexible hours)

- Regular appreciation by the immediate management and the organization as a whole

- Competitive pay, which employees maintain a good quality of life

- The promise of career progression in sync with employees' personal growth targets

Job security is the probability that an individual will keep their job; a job with a high level of security is such that a person with the job would have a small chance of losing it.

Basic economic theory holds that during periods of economic expansion businesses experience increased demand, which in turn necessitates investment in more capital or labor (Manavalan, 2016). When businesses are experiencing growth, job confidence and security typically increase. The opposite often holds true during a recession: businesses experience reduced demand and look to downsize their workforces in the short term.

Governments and individuals are both motivated to achieve higher levels of job security. Governments attempt to do this by passing laws (such as the U.S. Civil Rights Act of 1964) which make it illegal to fire employees for certain reasons. Individuals can influence their degree of job security by increasing 
their skills through education and experience, or by moving to a more favorable location. The official unemployment rate and employee confidence indexes are good indicators of job security in particular fields. These statistics are closely watched by economists, government officials, and banks.

Unions also strongly influence job security. Jobs that traditionally have a strong union presence such as many government jobs and jobs in education, healthcare and law enforcement are considered very secure while many non-unionized private sector jobs are generally believed to offer lower job security, although this varies by industry and country.

The study is conducted to know how this pandemic has affected our country's economy in this tough time. The study wants to know what the current situation of employees of different industries is.

\section{SIGNIFICANCE OF THE STUDY}

In view of practitioners, this study will be helpful in more understanding impact of covid-19 on employee's job security and job satisfaction of Bangladesh perspective. Cavernous study on organizational behavior will be fruitful for practitioners in order to have knowledge about the job security and job satisfaction. On the other side, the portrait of academic world will find it supportive in having awareness about the situation of employees in current covid-19 situation in Bangladesh. In real terms, this study will be more useful for academic world, as they are still not in the practical field and have only basic knowledge the present subject. Thus, they will find it more informative to get awareness in the depth about the current topic.

\section{PROBLEM STATEMENT}

Today's world pandemic has huge impact on world economy. This has also affected the employee's life also heavily. Their job satisfaction and job security are not the same as before that has changed due this corona pandemic. The covid-19 pandemic has created problem for the employees. So, this research wants to know how job satisfaction and job security of the employees of Bangladesh are doing in this Covid-19 Situation. We are going to discuss about the whole job situation of current world. For this we are going to conduct samples from employees of different industry.

\section{RESEARCH QUESTIONS}

The research questions of this research are as follows:

a) What are the current situations of various industries?

b) What are the factors to measure the employee's job security and job satisfaction in this pandemic?

c) What is the situation of employees?

d) What is the role of Covid-19 pandemic on Bangladesh's Economy?

e) How the economy can recover from it?

f) Are employees satisfied with job?

g) Are employees feeling their job is secured?

\section{OBJECTIVES OF THE STUDY}

- To know the current situation of various industries.

- To measure the employee's job security and job satisfaction in this pandemic.

- To analyze the current situation of employees.

- To know the role of pandemic in Bangladesh economy by measuring the situation of employee.

\section{SCOPE OF THE STUDY}

This study covers measurements of job security and job satisfaction of employees in this pandemic for a country level analysis of Bangladesh. The study uses primary data collection method by a survey questionnaire for collecting data from the employees of different organization. 


\section{RESEARCH GAP}

Many researchers have done researches in Job satisfaction and Job security of employees. But no one has done it in pandemic situation. Job satisfaction at the time of COVID-19: An investigation of information technology sector in India by Shilpi Arora (Faculty of Management, Symbiosis International University, Pune) \& Dr. Sandeep Vyas (Assistant Professor, The IIS University, Jaipur). They have done the research in this pandemic but they did not measure the job security of employee and they only done the research on IT sectors employees in India. Here the researcher wants to measure the job satisfaction and job security of employees from various industries.

Job Satisfaction Effecting Factors of Employees in Bangladesh Banking Sector by Md. Sohel Rana where the researcher only discussed the job satisfaction factors of banking sector employees in Normal Economic situation. In this paper the researcher wants to show the factors effecting job satisfaction and job security of employees from various industries in this current downward economic situation.

The impact of job security on employees' commitment and job satisfaction in Qom municipalities by Gholamreza Jandaghi*, Ali Mokhles and Hamid Bahrami (University of Tehran, Iran). Where the researcher wants to show the impact of job security on employees' commitment and job satisfaction. Here the researcher wants to show the impact of Covid-19 situation on employees Job security and Job satisfaction.

At last, we can say that no one has shown the Impact of Covid-19 on Job security and job satisfaction of employee at the current situation.

\section{REVIEW LITERATURE}

Impact of different factors on job satisfaction has been analyzed in the literature. Some studies focus on demographic determinants of workers job satisfaction but, the others relate it with nature of work and working conditions at the workplace. Similarly, fair promotion system in the organization, job autonomy, leadership behavior, social relations and the job itself are also among the important factors of job satisfaction (Dawson, 1987). The effect of rank, age, gender and length of service on job satisfaction of employees was studied by Oshagbemi (2003) for the universities in United Kingdom. The study found individual's rank within the organization as a major predictor of job satisfaction and there was positive and strong correlation between the two. Similarly, the length of service was significantly and negatively correlated to the job satisfaction. But the relationship between job satisfaction and age and gender was found to be insignificant for employees of the UK universities.

There is a lot of discussion in literature on the role of gender in job satisfaction but, there is a great controversy in the findings of different studies. Some studies found that women employees are more satisfied with their jobs than men employees but, the other studies on the gender issue prove the opposite (Weaver, 1974; Shaprio \& Stern, 1975; Forgionne and Peters, 1982; Clark, 1997; Ward \& Sloane, 1998). While discussing the gender aspect of job satisfaction, Cambell et al. (1976) argued that there is a difference between the expectations of men and women regarding their jobs. According to him this difference in expectation may be the cause of difference in the level of job satisfaction between women and men. According to Lee and Ho (1989) participation of employees in decision making process adds positively in employee's job satisfaction. Job satisfaction and work motivation among the managers of Chinese restaurant in Hong Kong was studied by Lam et al. (2001). The result of the study showed that the job itself, work environment and rewards are the important determinants of job satisfaction in that industry. They found that turnover intentions have a significant relation with job satisfaction. According to Tanke (1990) unpleasant behavior of supervisor, dissatisfaction with compensation system and disagreement with human resource practices make employees willing to leave the organization. Using the longitudinal data, Nguyen et al. (2003) studied the Determinants of job satisfaction by including personal traits, job autonomy, working hours, leadership behavior, actual pay and relative. There are three types of teams in organizations that are termed as quality circles, employee involvement teams, and self- directed work teams. 
According to Eason (1989) lack of training, insufficient support of top management and workers union and non-supportive behavior of super- visors are major impediments in building empowered teams. Despite prevalence of out-dated system in an organization empowered work teams may work and flourish, but ultimately it will require the revision to improve the organization's system (Emery, 1992). Improper planning is among the biggest mistakes made at the time of teambuilding and attractive reward system is the easiest thing to forget. For the prosperity and survival of self-directed teams, intrinsic as well as extrinsic reward systems play a vital role (Hackman, 1990). Chow and Luk (1996) identified good working relationships with supervisors. It is very important to look into the factors behind the declining job satisfaction. Satisfaction level of the employees working as a team is very important because it directly affects their performance on the job. Identification of these factors accurately becomes the key to retain and raise the satisfaction level of the employees (James, 1996).

The controversy in the literature, regarding the relationship between level of job satisfaction and gender, leads the following hypothesis: H0: There is no significant difference between men and women' job satisfaction level. H1: There is a significant difference between men and women job satisfaction level. $\mathrm{H} 2$ : Autonomy has significant impact on job satisfaction Garrido et al. (2005) studied the factors that determine the job satisfaction of sales managers.

The study concludes that human resource management practices-based compensation type, compensation level and job design in terms of autonomy and resources are the essential determinants of sales managers' job satisfaction. H3: Leadership behavior has significant impact on job satisfaction. Markow and Klenke (2005) and Milliman et al. (2003) documented that leadership spiritually is a major determinant to enhance the employees' efficiency, job satisfaction, and loyalty coupled with a decrease in employees' turnover intentions. According to Hackmanand Oldham (1980) job satisfaction is a multifaceted phenomenon that consists of factor such as supervision at work, work itself, compensation and benefits, pro- motion policies of organization, appraisal and co-workers' attitude. People are much concern about pay and leadership behavior. H4: Team work environment has significant impact on job Satisfaction Patel and Cardon (2010) suggest that having a group culture is a key factor in the extent to which leadership behavior is adopted, as well as how effective adopting HRM practices are for increasing labour productivity and job satisfaction. Gogoi (2005) find that the importance of work spiritually is consistently growing as the spiritual cause leads to strategic benefits to the business unit and due to the significant contribution of team work spiritually.

\section{RESEARCH METHODOLOGY}

In the proposed study we use mixed method primary data collected from employees of various organization. This study is mostly qualitative in nature and it deals with the current pandemic situation of Bangladesh. In this study, we use both primary and secondary data. We asked 14 questions to employees from various industries to measure how the covid-19 pandemic affected the job security and job satisfaction of employee. For this I have collected data from the 100 employees of different organization. Primary information has been collected by the survey questionnaire through Google docs and direct interview method. Secondary information published in internet, different author's research paper have been used as sources of data.

\section{RESEARCH DESIGN}

The research is based on secondary data. Which is collected by the survey questionnaire employees from various organizations? First of all I have set the number of objectives then reviewed the literature about it then collected data from the sources. Then I have analyzed the data from which I got the findings and at last I give the recommendations basis of findings.

\section{DATA COLLECTION STRATEGY}

In this study two types of data are used to perceive the Job Security and Job Satisfaction in the of different service sector employees due to emergencies like COVID-19 pandemic. We use both the 
primary and secondary data. In terms of collecting the primary data we make a questionnaire having 13 questions to find out the condition of the employee in service sector.

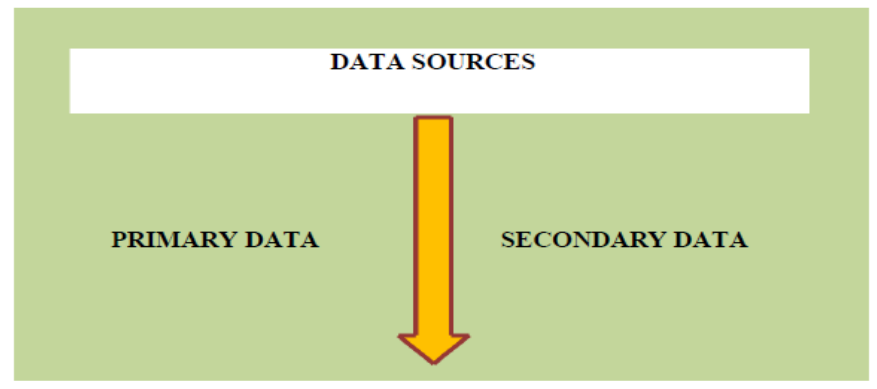

\section{THE CURRENT SITUATION OF VARIOUS INDUSTRIES}

According to the quarterly report of the Bangladesh Bank, 1.12 million people were unemployed in the service sector, 781,000 people were unemployed in the agriculture sector, and 695,000 people were unemployed in the industrial sector in 2020.There was also an estimated 66.6 million drop in the labor force- 22.3 million, 12.2 million, and 26.1 million, respectively, in agriculture, services, and the industrial sector. The service sector, which entails transport, tourism, hotels, motels, restaurants, housing, and construction, has been directly affected by the lock down, which has resulted in a higher number of unemployed and a reduction in income, explained Prof Mustafizur Rahman, distinguished fellow of the Center for Policy Dialogue (CPD) .Apart from the service sector, overseas employment was also largely affected in 2020 and 2021, until February, due to the ongoing pandemic, according to the central bank's quarterly report. "Although policy support was very effective to revive the employment generation across different sectors, further study is needed to assess the impact of the implementation of stimulus packages targeted for retention of labor markets in a way to ensure an even recovery across the sectors, areas, and gender in near future," the report concluded. Furthermore, according to the BB report, although policy supports were very effective to revive the employment generation across different sectors, a further study is needed to assess the impact of the implementation of stimulus packages targeted for retention of labor markets in a way to ensure an even recovery across the sectors, areas, and gender in near future (Williams, 2020). The report also showed male workers in the industry and services sector were hit hard with the compound annual growth rate (CAGR) for the female labor force standing at $4.4 \%$, while it was $2.8 \%$ for the male in urban areas during the years between 1999-2000 and 2020. In the agriculture sector, although 7.81 lakh people were left unemployed, the income of those employed in this sector has not decreased, rather increased $1.2 \%$ despite working hours decreasing by $3.8 \%$.

Additionally, agriculture subsidy for FY20 was increased for ensuring food security, and a refinance scheme was created for the working capital for the agriculture sector, to activate the agricultural labor force. Although all three major sectors of the labor market - agriculture, services, and industry were severely disrupted by the pandemic last year, the service sector seems to have hit the hardest. The government's stimulus package has mostly focused on the productive sector, while a large part of the service sector is informal, and does not fall under any government database, said Prof Rahman. But for individuals who have shifted from the service sector to the agriculture sector, their income compensation is low compared to their previous status, he added. Out of the three, the service sector accounted for around a $60 \%$ drop caused by loss of employment and income for a large number of people in the workforce. As per the report, total stimulus packages of Tk 18,580 cores were provided as agricultural subsidies for seeds, fertilizer, innovation, mechanization, and irrigation which helped the labor market in the sector to be activated during the Covid-19 period. Gunjan Dallakoti, small and medium enterprise (SME) development specialist of the International Labor Organization (ILO), told Dhaka Tribune that this also caused a stalemate where there was almost no migration of employment in overseas countries, while a huge number of overseas workers also returned to Bangladesh. According to the ILO's SME specialist, most migrant workers are employed in the tourism and hospitality sector that was badly hit 
because of borders shutting down and economies going into lock down. According to the Labor Force Survey (2017), 85\% of people are employed in the informal sector in Bangladesh.

Mohammad Anik, whose family business consists of sending workers to Saudi Arabia, told a national da that border shutdowns caused demand for Bangladeshi workers to drastically fall in the Middle Eastern country. In the case of rural areas, the CAGR for the female labor force was $4.8 \%$, while it was only $0.8 \%$ for the male during the periods including the Covid-hit year of 2020. The income of those employed in the service sector also decreased by $17.6 \%$.

According to $\mathrm{BB}$, this was mostly because female entrepreneurs- a large number of which reside under the CMSME sector- can easily avail loans from the stimulus packages. According to Prof Mustafizur Rahman, this was mostly caused by people migrating from the city centers to rural areas facing unemployment and getting involved in agriculture.

This was mostly caused by the 66-day general holiday to curb the spread of Covid-19, as well as the subsequent failure in making a turnaround, according to experts. Agriculture affected, but not as much.

\section{SECTORAL IMPACT OF COVID-19'S}

\section{Impact on Manufacturing Sector}

After China, Bangladesh boasts the world's second-largest clothing industry. It makes almost $\$ 35$ billion annually from exports to the US and Europe and employs roughly 4 million people, mostly rural women. The garment sector generates 84.21 percent of total exports and 20 percent of GDP for the country (Antara,2020). The pandemic canceled or suspended almost $\$ 3$ billion in orders, according to Bangladesh Garment Manufacturers and Exporters Association President Rubana Huq (Aslam, 2020).

Workers in the RMG industry are also affected by anxiety about the future of their careers because of the uncertainty surrounding it. Reports of rapes and suicide instances among female RMG employees during the COVID 19 epidemic might have long-term effects on their mental health (Kabir, Maple, \& Usher, 2021)

Due to a lack of raw resources, manufacturers must cease operations. A survey found that $93 \%$ of Bangladeshi garment producers experienced delays in raw material supplies due to the epidemic. A survey revealed that $72.4 \%$ of Bangladeshi firms couldn't pay their workers when they were furloughed. When orders were cancelled and workers were fired, over $80.4 \%$ of Bangladeshi suppliers said they couldn't compensate them (Anner, 2020)

To protect employees' health and general wellbeing during the COVID-19 pandemic, global health communities, BGMEA, international brands/retailers, the GoB, and the International Labor Organization (Kabir et al., 2021) suggest immediate coordinated and effective efforts by all parties.

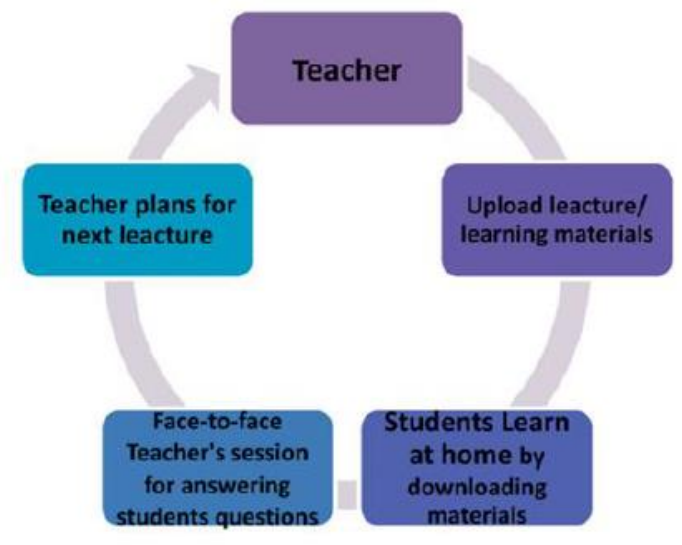




\section{Impact on Education}

The proliferation of corona virus, which has caused several problems, has prompted many countries to close their educational institutions. The corona virus pandemic has had a profound effect on education and public health. A study conducted by Salmi, Arnhold and Bassett (2020) found Limited resources and poor infrastructure have made it impossible for governments in many developing countries, like Bangladesh and Nepal, to make the change smoothly. According to Biswas et al. (2020), the majority of university students have a favorable attitude toward mobile learning. This study established that mobile learning is extremely beneficial for resolving study gaps during this COVID-19 pandemic period.

\section{Impact on Employment}

Mr. Mostafiz Uddin, the Managing Director of Denim Expert Limited, predicted that a small number of clothing employees will lose their jobs as a result of the COVID-19 (Uddin, 2020, March 24). (Sakamoto, Begum \& Ahmed, 2020) observed that significant economic losses are unavoidable, and many garment sector workers may be unable to find work for a longer duration. Out of Bangladesh's 63 million employees, about 25 million earn a wage/salary, with over 10 million earning daily pay. Around 4.5 million casual workers in construction, transportation, trade, food and lodging were severely impacted by the Covid-19 (Islam, 2020)

Across industries, a large number of people may lose their employment. Although employees in the dairy, poultry, transportation, and tourist industries face job loss, it is the RMG business that faces the greatest job loss (Table-2). Furthermore, a sizable number of self-employed workers, around 5.19 million self-employed workers in the urban informal sector, live-in insecure circumstances (Islam,2020)

Most RMG firms have decreased worker pay. If they regularize the pay, the workers may be more motivated. A minimal risk premium may be imposed for garment workers who contract COVID-19 or die from it. In this epidemic condition, 1-2 percent profit sharing with workers may be motivating (Islam, Hassan, Hassan, Rahman, \& Nargis, 2020).

\section{Impact on Social Life}

Various factors related to social life have a significant impact on economic wellbeing. So, we have to find out the problems that are created by the covid19 to address them. Domestic violence such as child marriage, marital rape, and physical torture continuously increased during pandemics. There were 4,622 women emotionally tormented in June 2020, 1,839 physically assaulted, 203 sexually molested and 3,009 women who had financial limitations placed on them by their spouses. (Manusher Jonno Foundation, 2020).According to another study, 107 women were murdered by their spouses between January and June of 2020, but only 74 cases were reported. Members of the husband's family were responsible for the deaths of 30 women, while members of the wives' families were responsible for the deaths of 26 women. Only 33 of the individuals filed any claims (Ain oSalish Kendra, 2020).

(Mahmud \& Islam, 2021) discovered that social stigma is caused by disinformation, uncertainty, fear of responsibility, administrative failure, and a lack of faith in treatment. Additionally, their study demonstrates that stigma has a variety of negative consequences, including health risks, harassment, discrimination, life insecurity, psychological distress, loss of social and emotional capital, shattered family bonds, and social solidarity, all of which act as barriers to social well-being.

The internet has become vital in modern life, yet regular usage might harm one's physical and emotional health. Extra free time during pandemic may have caused ennui among internet users. Its overuse during the epidemic may have aided problematic internet usage behavior, as noted by (Islam et al., 2020). They discovered that people from nuclear families utilize the internet more than people from extended families (Manavalan \& Donepudi, 2016).

There are some ways to overcome the problem in social life described by other authors are the following: 
It is strongly suggested that active surveillance and effective monitoring mechanisms be developed to help minimize the spread of disinformation via social and electronic media, as well as to enhance the state of mental health conditions during the pandemic (Hossain et al., 2020).

$>$ To protect mental health from Covid-19, a Confident and satisfying living place and society can help (Rahman et al., 2021).

$>$ To safeguard the health of older persons against covid-19, it is necessary to confirm the attitude of social care and health systems in ensuring welfare, promoting preventative measures, and facilitating access to healthcare (Hossain, Mazumder, Tasnim, Nuzhath, \& Sultana, 2020)

$>$ It is essential to introduce a time-oriented policy and implement care monitoring plans in the country, which may help manage the pandemic and nurture public mental health to combat COVID-19 related psychological challenges (Islam, Bodrul-Doza, Khan, Haque, \& Mamun, 2020)

Medical facilities such as testing, tracking, formal quarantining, and special treatment for corona virus in corona virus hospitals should be strengthened and decentralized to protect social stigma. This can be done by allocating significant state funds and also by implementing publicprivate partnership initiatives for health management (Mahmud \& Islam, 2020).

\section{Impact on Tourism Sector}

To stop the virus from spreading, all governments have enforced lockdowns and limited travel. Tourism is linked to human movement, which is hampered by travel restrictions. Tourism in Bangladesh is slowly increasing due to a large domestic travel market. Due to the epidemic, both domestic and foreign visitors canceled. However, due to various travel restrictions, all flights have been canceled. As a result, businesses lose money and workers lose jobs (Deb \& Nafi, 2021). According to industry experts, over 4,000 million people are employed by tour operators, hotels, resorts, airlines, and food businesses that are currently fighting to stay afloat. According to a research released by the Tour Operators Association of Bangladesh (TOAB) in April 2021, the loss is expected to be Tk 57 billion by the end of 2020. The National Board of Revenue (NBR) received Tk 3.28 billion in travel tax during the previous fiscal year, less than half of the amount collected the year before. Tk 7.66 billion in travel tax was collected in FY 20. By 2021, air traffic would have decreased by $60 \%$, while the airline sector will have lost US $\$ 370$ billion due to the epidemic, according to an ICAO assessment released on January 15th (Mala, 2021).

Local residents who rely on visitors stated that they would be able to compensate for the closure's losses. According to the Rangamati Chambers of Commerce and Industry, travel operators together lost Tk 2.15 crore. While the second wave of the epidemic was ravaging the country, the government authorized all tourist attractions, community centers, resorts, and places of leisure to reopen on August 19 with a 50 percent capacity and observe all Covid-19 safety standards (Dhaka Tribune, August 19, 2021).

COVID-19's effects on tourist employment place further strain on tourism education, which has been badly impacted by the pandemic. Apart from the virtualization of teaching and learning processes, tourism students and graduates must contend with the cessation of industry internships, recruiting, and dubious career options (Sigala, 2020).

\section{THE EMPLOYEE'S JOB SECURITY AND JOB SATISFACTION IN THIS PANDEMIC}

$\begin{array}{cc}\text { Level on the organization } & \text { People } \\ \text { Top Level } & 9(9.1 \%) \\ \text { Mid-Level } & 86(86.4 \%) \\ \text { Lower Level } & 5(4.5 \%)\end{array}$




\section{Data Table 1: Data Analysis}

\section{What is your position in the organization?}

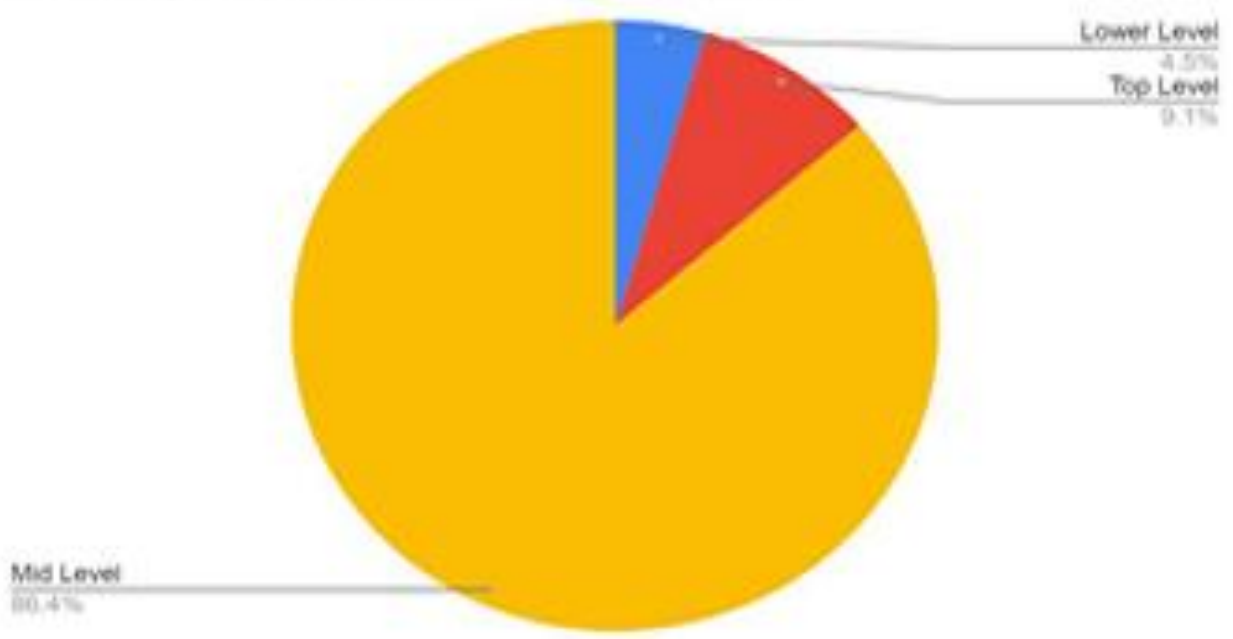

Comment: From this paper we can see that this research is conducted between mid-level employees. Because most of the employee has responses from mid-level of the organization.

\section{Data Table 2: \\ Working Period People \\ 1-5 years $\quad 69(69.2 \%)$ \\ 5-10 years $\quad 19(19.2 \%)$ \\ 10-20 years $\quad 8(7.7 \%)$ \\ $20+$ years $\quad 4(3.8 \%)$}

What's your company situation In this Pandemic?

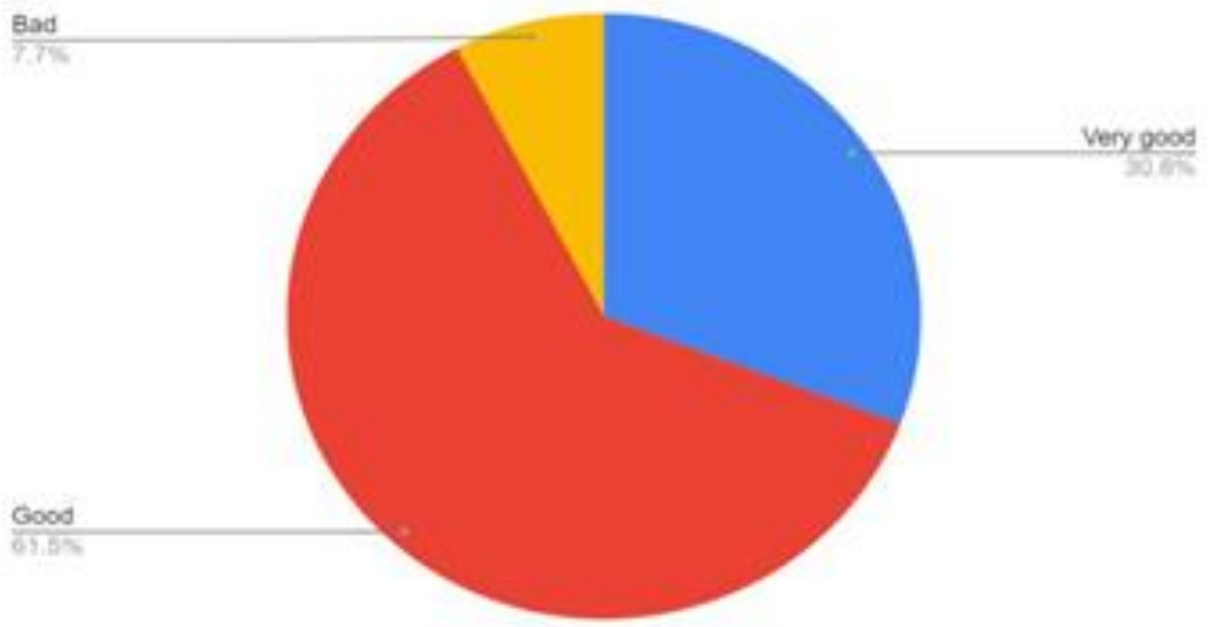

Comment: From this data table we can see that most the employees who have responded in this research paper most of them are working in the 1-5 years' time frame that means the paper deals with the young fresh job holders.

\section{Data Table 3:}

Company's situationPeople

Very Good 31(30.8\%)

Good 61(61.5\%)

Bad $8(7.7 \%)$ 


\section{How many years are you working in the current Job?}

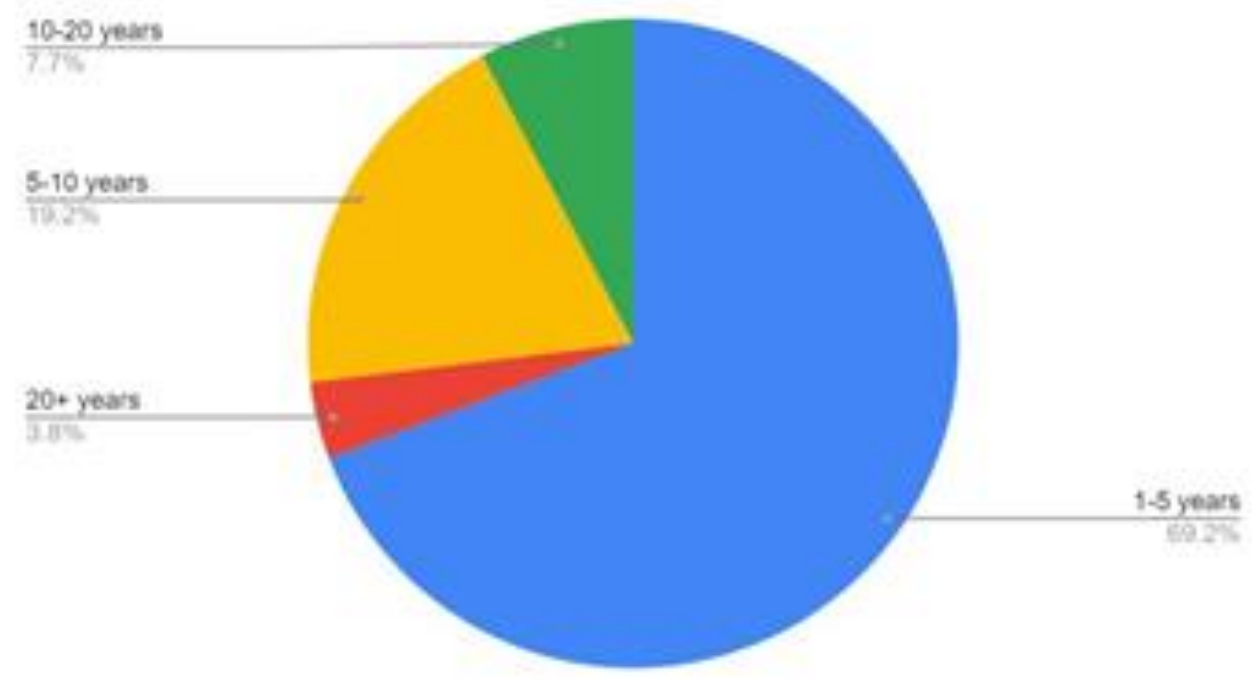

Comment: From this graph we find that most of the employee have said that their organization are in the good position where the degree if measurement was bad, good and very good. That means most of the organizations are in the middle positions in this pandemic situation.

\section{Data Table 4:}

Sacking Employees People

Yes $\quad 47(47.1 \%)$

No $53(52.9 \%)$

\section{Are your company sacking its employee?}

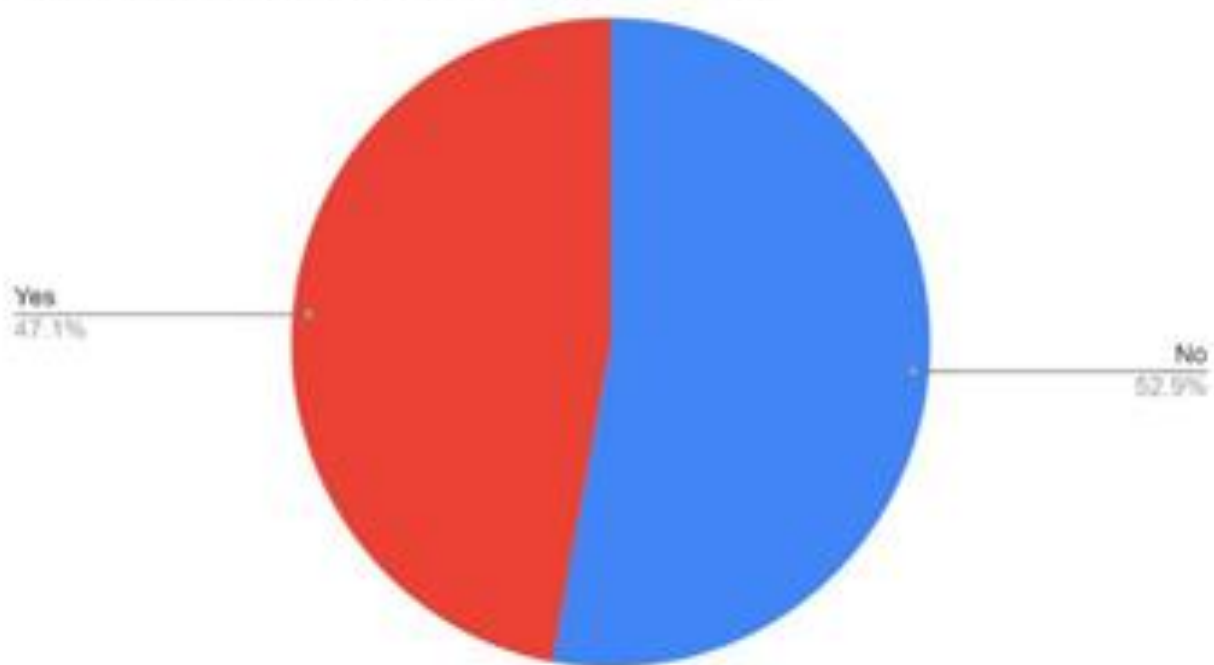

Comment: In this data table we can know that most of the organizations are not sacking their employees. But the difference between yes and no are not in the big margin the margin of sacking and not sacking is very small. So we can say that most of the organization is not sacking their employee.

\section{Data Table 5:}

Pay Cut People

Yes 20(20\%)

No $\quad 80(80 \%)$ 


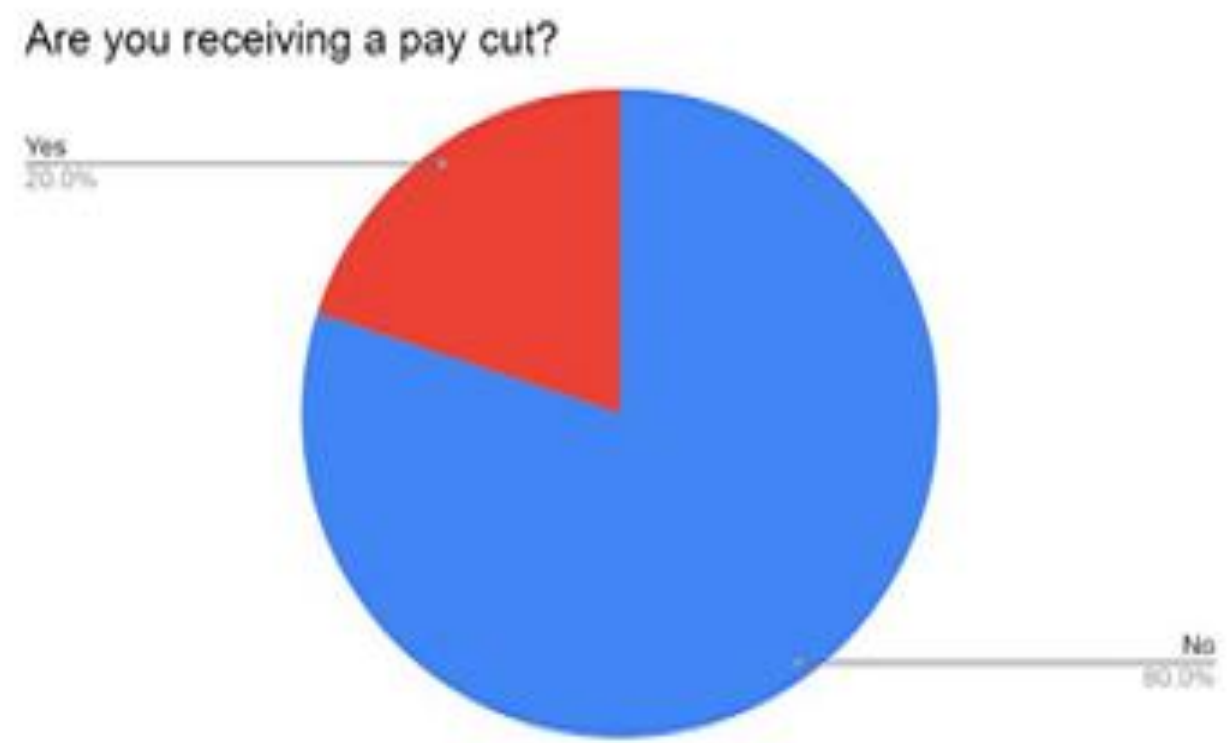

Comment: From this chart we can see that most of the employees are not receiving a pay cut. $80 \%$ of the employees from this research they are saying they are not receiving pay cut from the organization.

\section{Data Table 6:}

Salary Deduction from other employee People

Yes $28(28 \%)$

No $72(72 \%)$

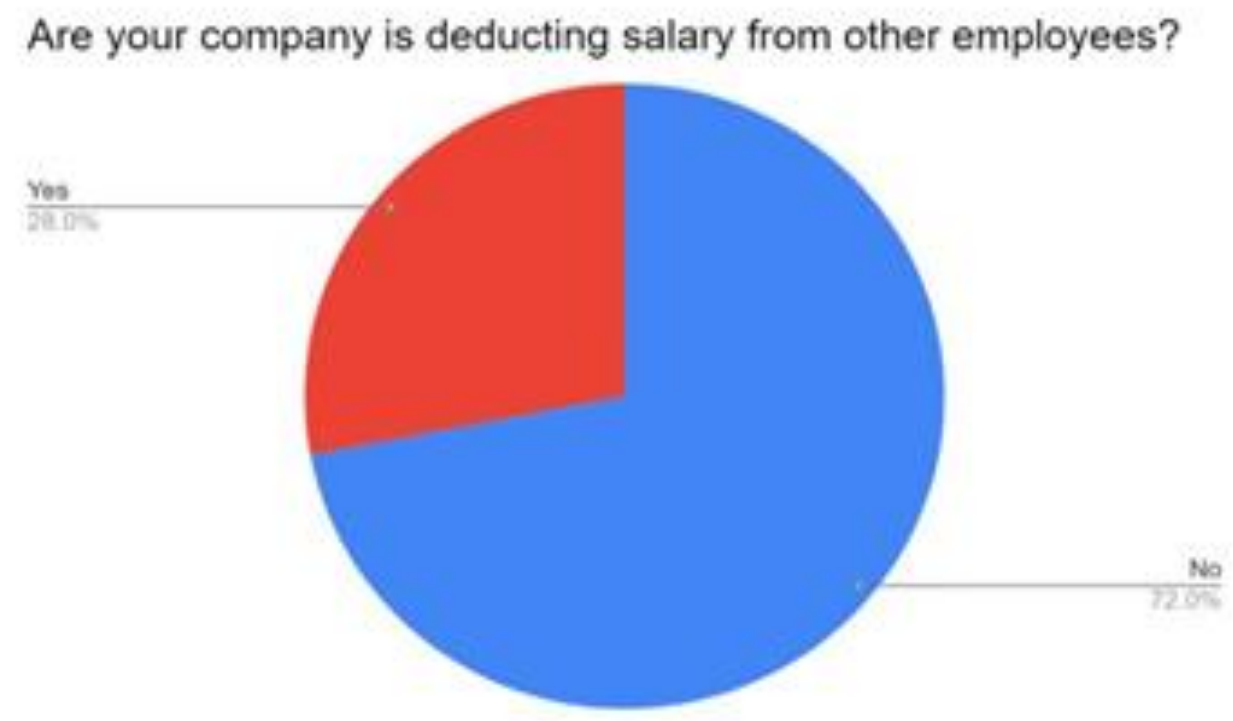

Comment: From this data table we can see that the employees have said that most of the companies are not deducting salary from the other employees. Which is good for the pandemic situation?

\section{Data Table 7:}

Level of Salary deduction People

Top Level

Mid-Level

$41(41.2 \%)$

Lower Level

24(23.5\%) 


\section{From which level the salary is deducting?}

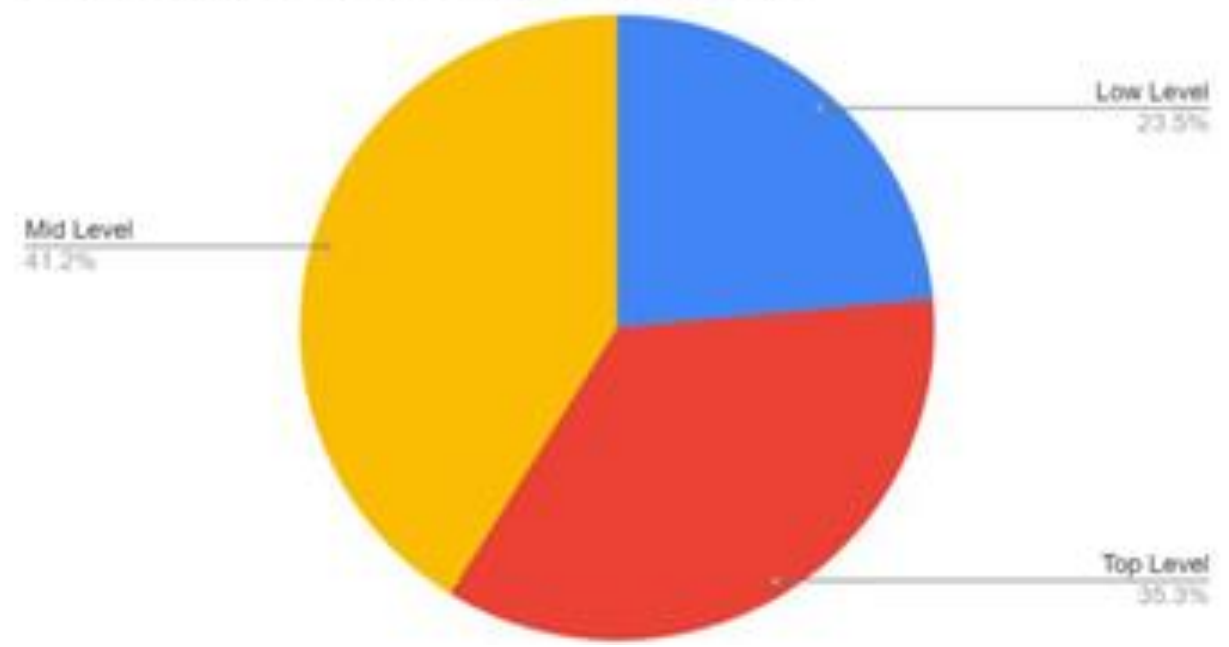

Comment: From this table we can say that most of the level of salary deduction is mid-level then from top level and at last lower level. Which is good in one way because in this situation the lower-level employees of any organization have affected most?

\section{Data Table 8:}

Salary regularity People

Yes

No

\section{Did you get your salary regularly in this pandemic?}

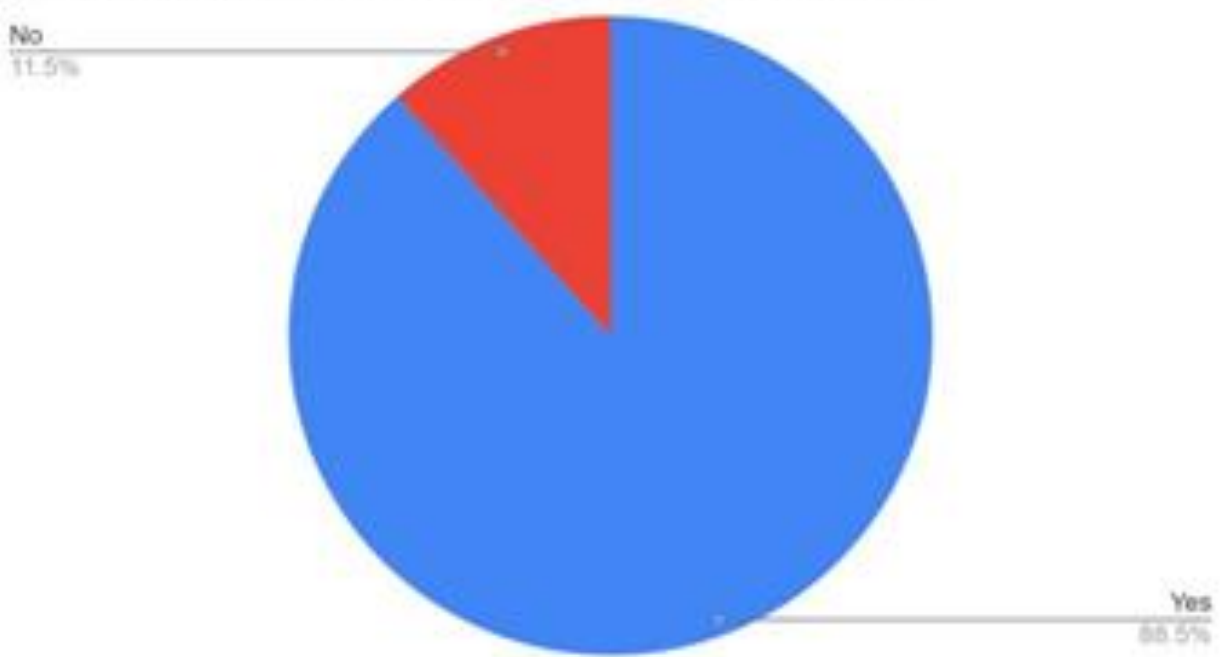

Comment: From this chart we can see that $88.5 \%$ organizations are paying salary to their employees on time. Where the irregularity is $11.5 \%$ so we can say that the most of the organizations are paying regularly to their employees.

\section{Data Table 9:}

Pandemic Holidays People

Yes $92(92 \%)$

No $8(8 \%)$ 


\section{Did your company give you pandemic holidays?}

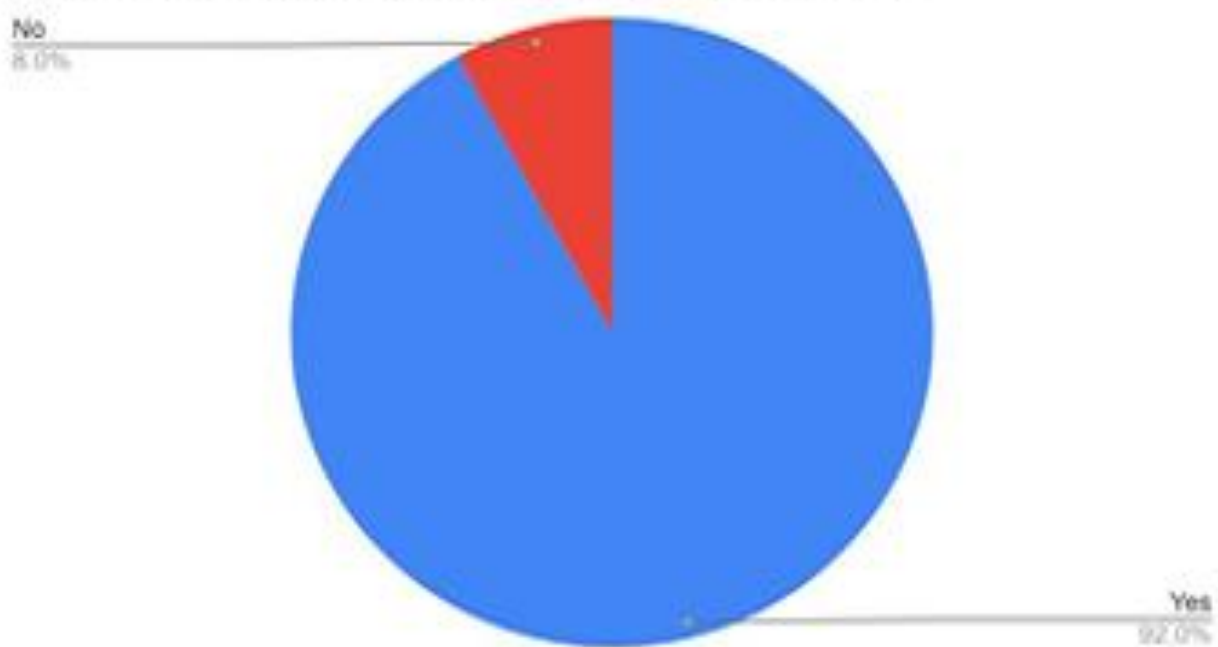

Comment: From the data table we can say that 92 people have responded that their organization is giving pandemic holidays to them. That means organizations are thinking about their employees which will satisfy them.

\section{Data Table 10:}

Health Regulations People

Yes $88(88 \%)$

No $12(12 \%)$

\section{Do your company maintaining health regulations during}

\section{pandemic?}

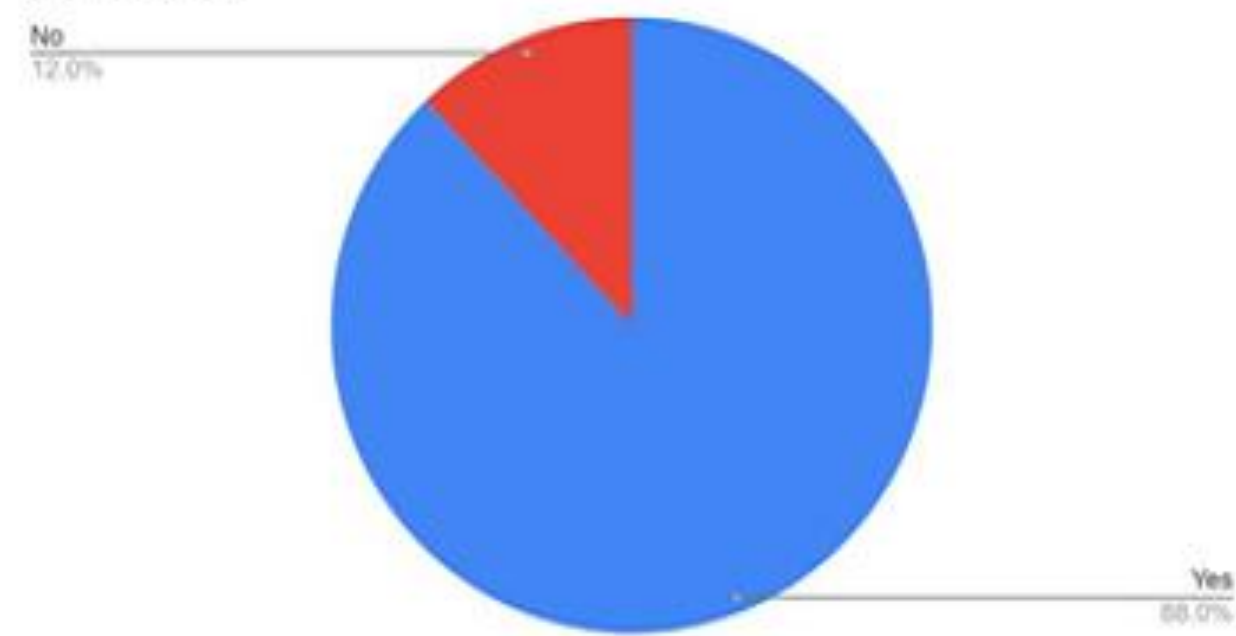

Comment: From the chart we can say that most of the organizations in Bangladesh are maintaining health regulations in this pandemic situation. Which is good for the health security of the employee?

\section{Data Table 11:}

Preference of Work from home People

Yes 64(64\%)

No $36(36 \%)$ 


\section{Did your company preferred work from home?}

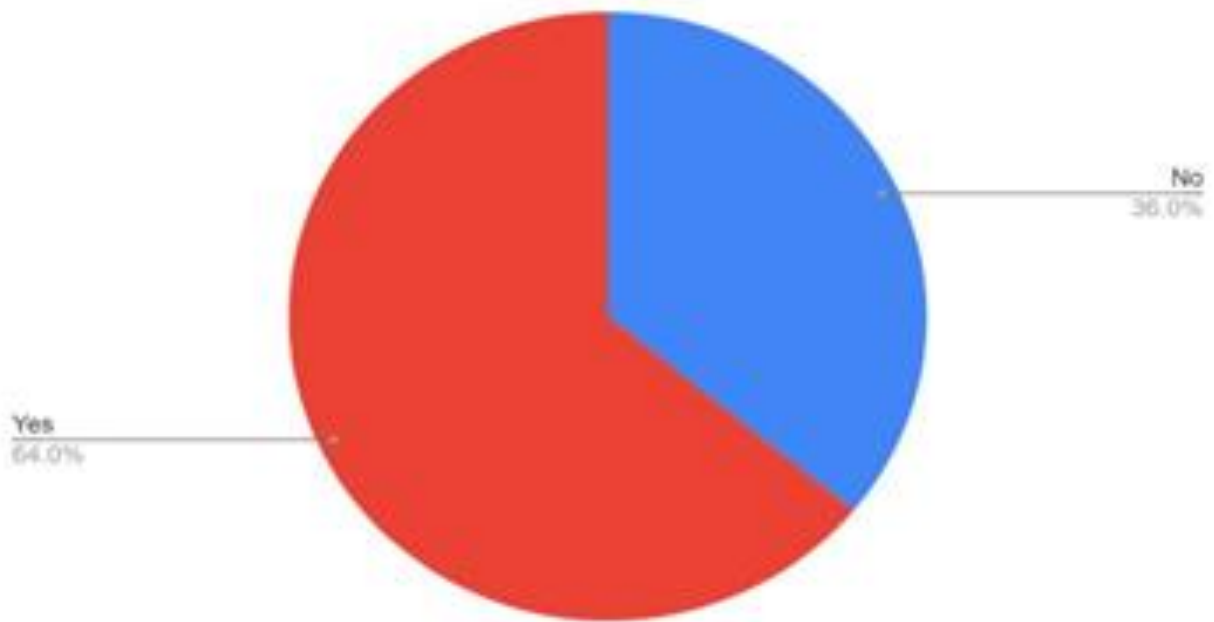

Comment: From this chart we can see that most of the organizations now prefer work from home. This is good in this pandemic situation that organization is securing the health safety of employees.

\section{Data Table 12:}

Festive Bonus People

Yes $68(68 \%)$

No $32(32 \%)$

Did your company pay you festive bonuses?

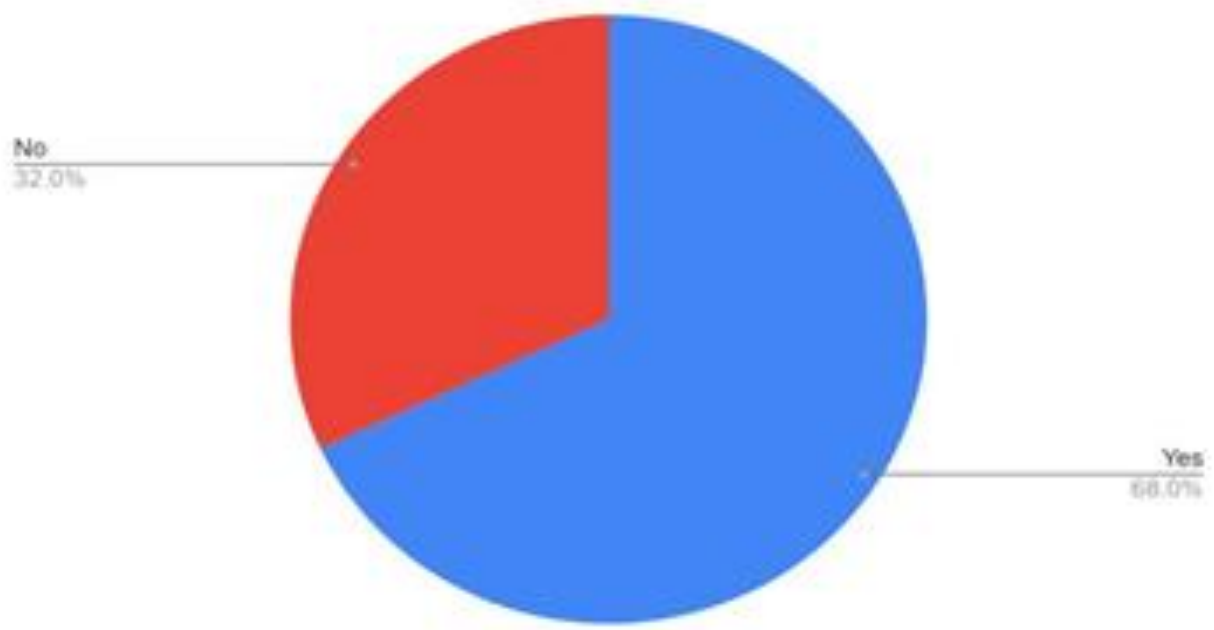

Comment: From the chart we say that most of the organizations are paying festive bonuses for the employee. Which means they are ensuring the job satisfaction in the Covid-19 Pandemic which is good for the employee?

\section{Data Table 13:}

Hiring New people People

Yes $80(80 \%)$

No $20(20 \%)$ 


\section{Do your company hiring new people?}

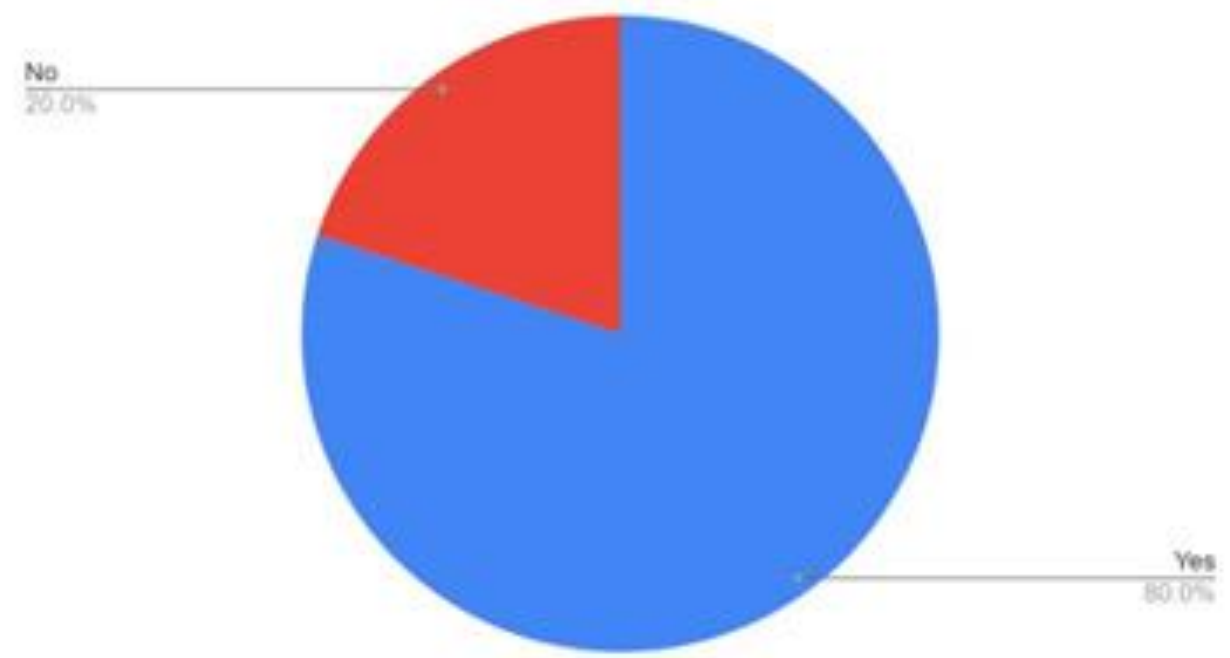

Comment: From the chart we can say that organizations are hiring new people for their organizations which are good for the economy. The fresher's who have entered in the job market that's good news for them.

\section{Data Table 14:}

Recovering from covid-19 situation People

Yes $85(84.6 \%)$

No $15(15.4 \%)$

\section{Do you think that your company can recover from Covid-19}

\section{Situation?}

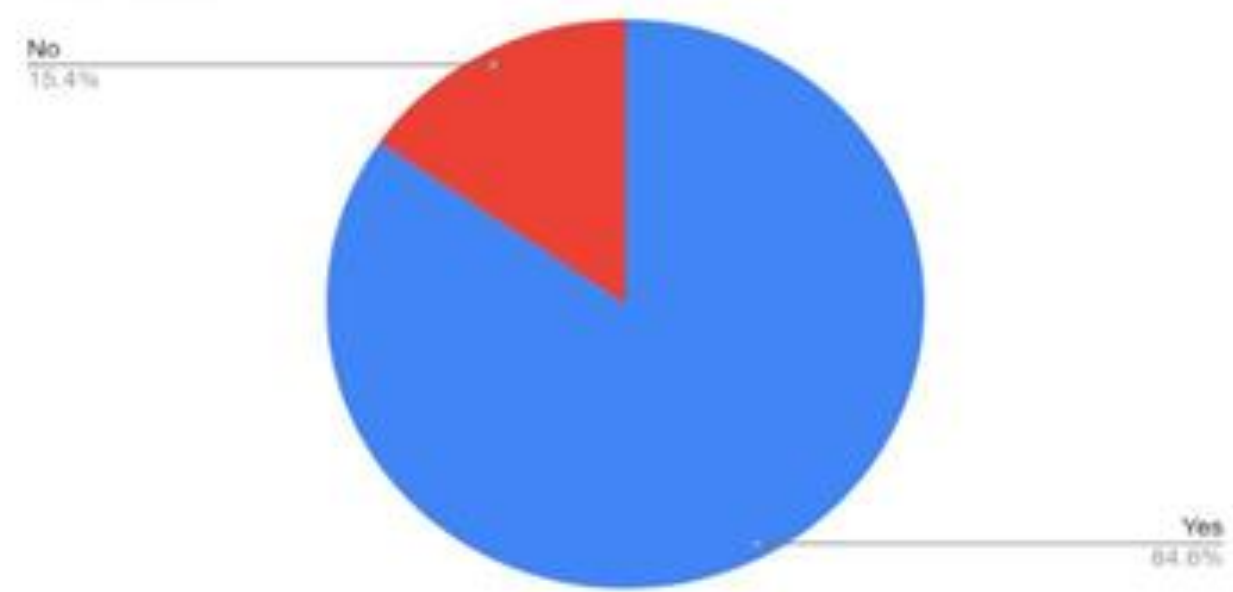

Comment: From this data table companies can recovers from this pandemic situation. Which is good for the economy? That means economy is heading towards good situation from it.

\section{SHORT COMINGS OF THE STUDY}

To make a report various aspects and experience is needed. But I faced some barriers for making report. These barriers hinder our works are as follows:

- Difficulty in accessing data of its internal operations

- Some information was confidential to the company

- Some Data are not reliable

- Non-availability of some proceeding 
FINDINGS \& ANALYSIS

i. Most of the employees in this research are the mid-level employee so we can say that it will measure the job satisfaction and job security of employees in this pandemic

ii. Most of the employee says that their organization is in good position that they have the job security.

iii. Most of the companies are not sacking its employee which secures employees job

iv. Most of the companies are not cutting their salary which ensures employees job satisfaction.

v. Companies are deducting salary mostly from top level and mid-level.

vi. Organizations should paying their salary regularly.

vii. Most of the Organizations have given pandemic holidays.

viii. Companies are maintaining health regulations in this pandemic

ix. Organizations nowadays prefer work from home.

x. Most of the employees received festive bonuses.

xi. Organizations are recovering from the covid-19 losses

xii. Now they are creating new vacancies.

\section{RECOMMENDATIONS}

$>$ Governments should help the organizations from recovering covid-19 losses.

$>$ Organizations should maintain the health regulations in this pandemic.

$>$ Organizations should ensure the job satisfaction of employees in this pandemic.

$>$ Organizations should ensure the job security of employee in this pandemic.

$>$ The organization which can deal the work from home they should prefer work from home in this situation.

$>$ Government should allot funds tax-rebates for recovering the economy condition quickly.

\section{CONCLUSIONS}

At last we can say that covid-19 has made a huge impact on the world economy as well as Bangladesh's economy. The whole world is trying to recovering from it. From this research we can say that various organizations from Bangladesh are trying to ensure the job satisfaction and job security of employee. Which is good for the employees?

\section{REFERENCE}

Campbell, A.; Converse, P.E.; Rodgers, W.L."The Quality of American Life. Perceptions, Evaluations, and Satisfactions" Russel Sage Foundation, 1976, New York, USA

Chow and Luk (1996)"Effects of Comparative Advertising in High-and Low-Cognitive Elaboration Conditions", March 2013Journal of Advertising 35(2):55-67, DOI:10.1080/00913367.2006.10639229.

Frank Markow, Karin Klenke (2005), "The Effects of Personal Meaning and Calling on Organizational Commitment: An Empirical Investigation of Spiritual Leadership", International Journal of Organizational Analysis, Volume 13 Issue 1, ISSN: 1934-8835

Guisseppi A. Forgionne, Vivian E. Peeters,"Differences in Job Motivation and Satisfaction Among Female and Male Managers"First Published February 1, 1982

H. J. Shapiro, L. Stern (1975), "Job Satisfaction: Male and Female, Professional and Non-Professional Workers" The Personnel journal, Psychology

Hackman J.R. \& Oldham G.R. (1980). Work Redesign.Philippines : Addison- Wesley

Kulik,C.T.,Oldham,G.R. and Hackman,J.R.(1987)Work Design as an Approach toPerson- Environment fit.Journal of Vocational Behavior,31,278-296.

Kulik,C.T.,Oldham,G.R. and Langer,P.H. (1988)Measurement of JobCharacteristics:Comparison of the Original and the Revised Job Diagnostic Survey.Journal of Applied Psycology,73(3),462-466. 
Lam et al. (2001),'Study of managerial job satisfaction in Hong Kong's Chinese restaurants" International Journal of Contemporary Hospitality Management 13(1):35-42

Locke, E.A. 1976. The Nature and Causes of Job Satisfaction. Chicago IL: Rand McNally

Manavalan, M. (2016). Biclustering of Omics Data using Rectified Factor Networks. International Journal of Reciprocal Symmetry and Physical Sciences, 3, 1-10. Retrieved from https://upright.pub/index.php/ijrsps/article/view/40

Manavalan, M., \& Donepudi, P. K. (2016). A Sample-based Criterion for Unsupervised Learning of Complex Models beyond Maximum Likelihood and Density Estimation. ABC Journal of Advanced Research, 5(2), 123-130. https://doi.org/10.18034/abcjar.v5i2.581

Manavalan, M., \& Ganapathy, A. (2014). Reinforcement Learning in Robotics. Engineering International, 2(2), 113124. https://doi.org/10.18034/ei.v2i2.572

Michael Zane Hackman \& Kim B. Walker (1990),"Instructional communication in the televised classroom: The effects of system design and teacher immediacy on student learning and satisfaction"Pages 196-206 | Published online: 18 May 2009.

Milliman et al. (2003)"Workplace spirituality and employee work attitudes: An exploratory empirical assessment", August 2003Journal of Organizational Change Management 16(4):426-447, DOI: 10.1108/09534810310484172

MousaKhani, M. (2005). Monshizade Nayin,Masoud, Organization and Management, Islamic Azad University of Qazvin, c. 2, Tehran.

Nguyen, C. V. ; Smulikowska, S. ; Mieczkowska, A., 2003. Effect of linseed and rapeseed or linseed and rapeseed oil on performance, slaughter yield and fatty acid deposition in edible parts of the carcass in broiler chickens. J. Anim. Feed Sci., 12:271-288

O. James, 1996"Public Management Reform: a Global Perspective" Vol.16, Issue3, September 1996, Pages 143-149.

O'Brien,G.E(1982) Evaluation of the Job Characteristics Theory of Work attitudes and Performance.Australian journal of Psycology,34(3).383-401.

Oshagbemi, T. (2003) Personal Correlates of Job Satisfaction: Empirical Evidence from UK Universities. International Journal of Social Economics, 30, 1210-1232.

Rogers, William. 2010. Fire Kills Garment Workers: Workers Protest Low Wages. The working conditions and wages of workers in the Bangladesh. leftlaborreporter.wordpress.com/2010

Ryan, A.M., M.J. Schmitt and R. Jonson. 1996. Attitudes and Effectiveness: Examining relations at an organizational level. Personal Psychology, 49: 853-882

Siddiqi, G. Hafiz. 2005. The Readymade Industry of Bangladesh, (Second Edition). Dhaka, Bangladesh: The University Press Limited

Williams, R. T. (2020). A Systematic Review of the Continuous Professional Development for Technology Enhanced Learning Literature. Engineering International, 8(2), 61-72. https://doi.org/10.18034/ei.v8i2.506 